\title{
Masculinities of prostate cancer survivors: a qualitative metasynthesis
}

\author{
Masculinidades de sobreviventes de câncer de próstata: uma metassíntese qualitativa \\ Masculinidades de supervivientes de cáncer de próstata: una metassíntesis cualitativa
}

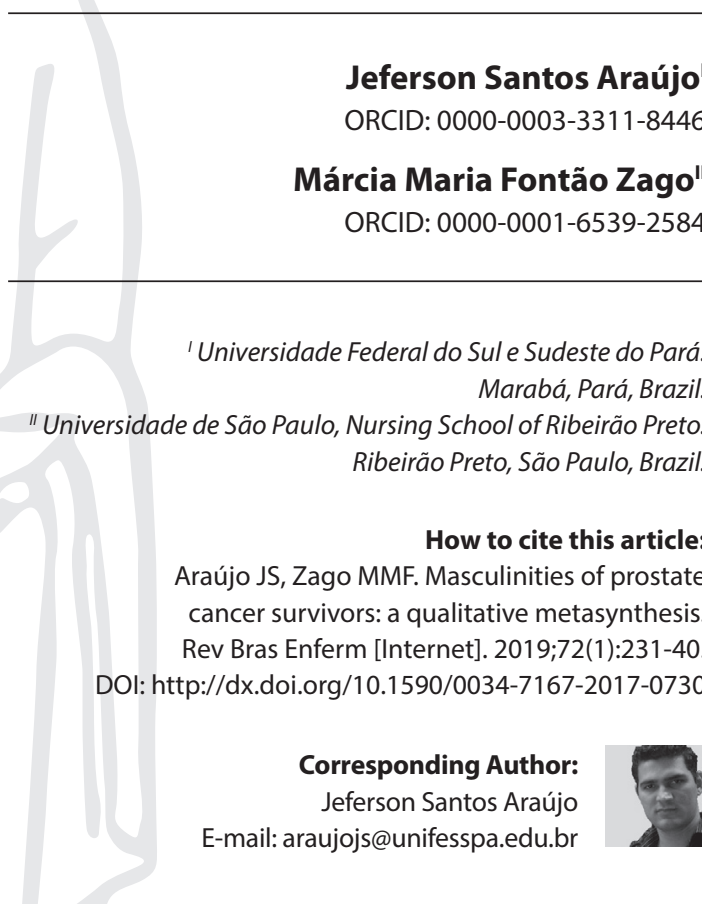

Submission: 10-23-2017 Approval: 06-14-2018

\section{ABSTRACT}

Objective: To identify the production of knowledge in the health literature about masculinities in the context of prostate cancer survivors and to analyze the implications of this relationship for the maintenance of health care. Method: Metasynthesis of 21 qualitative studies, performed in the LILACS, MEDLINE and CINAHL databases, with the scientific descriptors of DeCS and MeSH terms masculinity, prostate neoplasms. Results: Illness due to prostate cancer imposes numerous changes in male relationships, especially the non-dominance of the body and vulnerability to treatments and their consequences. The cultural values surrounding the disease and the hegemonic behaviors have implications for the health care of men. Conclusion: It has been shown that this relationship makes it difficult to communicate about the disease, marital relationships and family support, mainly influencing neglect of health. The knowledge produced is useful to promote the engagement of men in strengthening care.

Descriptors: Men's Health; Prostate Neoplasms; Nursing Oncology; Masculinity; Metasynthesis.

\section{RESUMO}

Objetivo: Identificar a produção de conhecimento na literatura da saúde sobre as masculinidades, no contexto dos sobreviventes do câncer de próstata, e analisar as implicações desta relação para a manutenção dos cuidados de saúde. Método: Metassíntese de 21 estudos qualitativos, realizada nas bases de dados LILACS, MEDLINE e CINAHL, com os descritores científicos do DeCS e MeSH terms masculinidade, neoplasias da próstata. Resultados: $\mathrm{O}$ adoecimento pelo câncer de próstata impõe inúmeras mudanças nas relações masculinas, sobretudo o não domínio do corpo e a vulnerabilidade frente aos tratamentos e suas consequências. Os valores culturais entorno da doença e os comportamentos hegemônicos, trazem implicações para o cuidado a saúde dos homens. Conclusão: Evidenciou-se que esta relação dificulta a comunicação sobre a doença, as relações conjugais e o apoio familiar, influenciando principalmente a negligência com a saúde. $O$ conhecimento produzido revela-se útil para promover o engajamento dos homens no fortalecimento de cuidados.

Descritores: Saúde do Homem; Neoplasias da Próstata; Enfermagem Oncológica; Masculinidade; Metassíntese.

\section{RESUMEN}

Objetivo: Identificar la producción de conocimiento en la literatura de la salud sobre las masculinidades, en el contexto de los sobrevivientes del cáncer de próstata, y analizar las implicaciones de esta relación para el mantenimiento de la atención de salud. Método: Metassíntesis de 21 estudios cualitativos, realizada en las bases de datos LILACS, MEDLINE y CINAHL, con los descriptores científicos del DeCS y MeSH terms masculinidad, neoplasias de la próstata. Resultados: La enfermedad por el cáncer de próstata impone innumerables cambios en las relaciones masculinas, sobre todo el no dominio del cuerpo y la vulnerabilidad frente a los tratamientos y sus consecuencias. Los valores culturales alrededor de la enfermedad y los comportamientos hegemónicos, traen implicaciones para el cuidado de la salud de los hombres. Conclusión: Se evidenció que esta relación dificulta la comunicación sobre la enfermedad, las relaciones conyugales y el apoyo familiar, influenciando principalmente la negligencia con la salud. El conocimiento producido resulta ser útil para promover el compromiso de los hombres en el fortalecimiento de los cuidados.

Descriptores: Salud del Hombre; Neoplasias de la Próstata; Enfermería Oncológica; Masculinidad; Metasíntesis. 


\section{INTRODUCTION}

Despite the growing advancement in Prostate Cancer (PC) control, the disease is still a significant public health problem worldwide, accounting for the second most common cause of cancer death among men. Estimates indicate that the USA, Northern Europe and Australia are the countries with the highest incidence of the disease ${ }^{(1)}$. In Brazil, for the years 2016 and 2017, 61,200 new cases were estimated for every 100,000 men, and it is one of those responsible for the increase in mortality among males ${ }^{(2)}$.

There are several modalities of treatments for PC, among them the main strategies used are the surgical removal of the prostate gland, radiotherapy, brachytherapy and hormonal therapy ${ }^{(3) .}$ However, such techniques contribute to increased survival, complications such as erectile dysfunction, loss of libido, reduction of sexual potency, and adoption of female characteristics such as decreased body hair, fat distribution and gynecomastia continue to be problems commonly encountered by men survivors of the disease, which threaten their physical and behavioral characteristics socially related to the male gender ${ }^{(4-5)}$.

In this perspective, masculine ideals such as strength, dominion, sovereignty over women and men, virility, aversion to socially recognized behaviors as feminine, and non-disease of the body, often defended in the hegemonic western cultures of healthy men, are confronted daily in the experiences of men who are survivors of the disease, and put at risk the defense of the ideals of male identity and the maintenance of health care ${ }^{(6-7)}$.

Masculinities are ways of being and being in the world that guide men within a socio-cultural system ${ }^{(8)}$. Thus, they conform to a position of power that the individual assumes in gender relations, that is, the practices by which men commit themselves to the masculine and feminine place in society, and the effects of these practices on body experience, personality and culture ${ }^{(9)}$. It is a sociocultural construction referring to a specific historical time, culture and the environment related to each individual ${ }^{(6)}$.

We argue that masculinities approach is not limited to a heteronormative conception that shows the difference between masculine and feminine within a category referring to the biological sex, but of gender (culture) ${ }^{(8)}$. In this way, masculinities are manifold as well as the cultural milieu where men share their experiences of health and illness, coexisting in this context subordinate masculinities, complicity, marginalized, local and global, which provide differentiated experiences to the PC survivors ${ }^{(10)}$.

The anthropological perspective presents some patterns of masculinities linked to the culture. Hegemonic masculinity as one of these patterns refers to patriarchy, to the paternalistic way of relating that distances itself from the behaviors considered as feminine; is characterized by the domination of men and the subordination of women beyond the exclusion of homosexuals. The masculinity of complicity has connections with the project of hegemonic masculinity, but without the complete incorporation of its attributes, since the men who adopt it enjoy some advantages of patriarchy. Marginalized masculinities refer to masculinities of dominant and subordinate classes or ethnic groups. The subordinate masculinities concern the relation of domination and subordination to groups of men or women, as it is the case of the domination of the heterosexual men on the homosexual men or women of both sexualities ${ }^{(9)}$.
These masculine relations of hegemony, subordination/domination and complicity, provide us with a theoretical framework in which we can analyze the masculinities inserted in a culture in a fluid and dynamic way in the face of events and changes in the cycle of life, which can lead man to a re-signification of their masculine identity.

It is due to the lack of previous revisions and the search to know which are the experiences already investigated involving the subject in question, that we justify the necessity of this metasynthesis. Given the context presented and, as nurses researchers of the socio-cultural relationships established among masculinities of ill men, we use the following question to guide this study: what are the meanings produced in the health literature about the relation established between masculinities and the PC survivors?

\section{OBJECTIVE}

To identify the production of knowledge in the health literature about masculinities in the context of prostate cancer survivors and to analyze the implications of this relationship for the maintenance of health care.

\section{METHOD}

To identify the knowledge described in the health literature, we chose to adopt the design of the qualitative systematic review of the metasynthesis type ${ }^{(11)}$. As masculinity is an analytical concept and its experience demands a subjective order, the PC coping experiences are not quantifiable, we justify the adoption of this design, by providing that the researchers gather results of qualitative data and group them into a set that makes it possible to identify and analyze the evidence, creating an overview of the men's experiences described in the literature about the phenomenon studied ${ }^{(12)}$.

We operated the review in an attempt to develop an analysis of the synthesis of knowledge in the area of interest. To do so, we follow the steps proposed by PRISMA, consisting of a checklist of 27 items regarding the structure of the article, and also offers a flowchart model[(13).

To answer the question of the study and to elucidate the proposed objective, double searches were carried out by different evaluators (first and last author), who worked independently in the selection of the articles, from the reading of their titles and abstracts. Faced with doubts about the adequacy of the studies, they were read in full and a third evaluator was consulted, reaching a consensus. This study used the recommendations described in the Enhancing Transparency in Reporting the Synthesis of Qualitative Research (ENTREQ) to report such a qualitative synthesis from the stages of research, identification and selection of articles, evaluation of selected articles, extraction of data and elaboration of the synthesis ${ }^{(14)}$.

Searches were carried out during the months of June to October 2016. We consulted the collections of Latin American and Caribbean Literature (LILACS - Literatura Latino-Americana e do (aribe) databases, Medical Literature Analysis and Online Retrieval System (MEDLINE) and Cumulative Index to Nursing and Allied Health Literature (CINAHL) where we used the scientific descriptors of DeCS (masculinidade AND neoplasias da próstata, in Portuguese) applied in the LILACS database, the MeSH (masculinity 
and prostatic neoplasms) and the MEDLINE and CINAHL, which in all bases were refined by the Boolean operator AND.

For the selection of items, they were established as inclusion criteria: original articles; being in Portuguese, English or Spanish; available in full text; (ethnography, phenomenology, among others), published between January 2008 and October 2016 (a cut justified by the creation of the Política Nacional de Atenção Integral à Saúde do Homem (freely translated as National Policy for Comprehensive Care to Human Health) in 2008, as a milestone in health care for men in Brazil); besides being developed by any professional category and published in any Health journal.

By means of the association of the descriptors in the electronic search, 54 articles were identified, which were selected first by the title, then by reading the abstract and then by reading the entire text. After this initial stage, the articles were submitted to the pre-established inclusion criteria in which 33 studies were not adequate for the study due to the following characteristics: being quantitative studies, reflection studies, mixed studies, review studies, not focusing on the concerned and because they are repeated between the databases. Thus, we aggregate the analytical corpus for this metasynthesis with 21 studies, as exemplified in the flowchart shown in Figure 1.

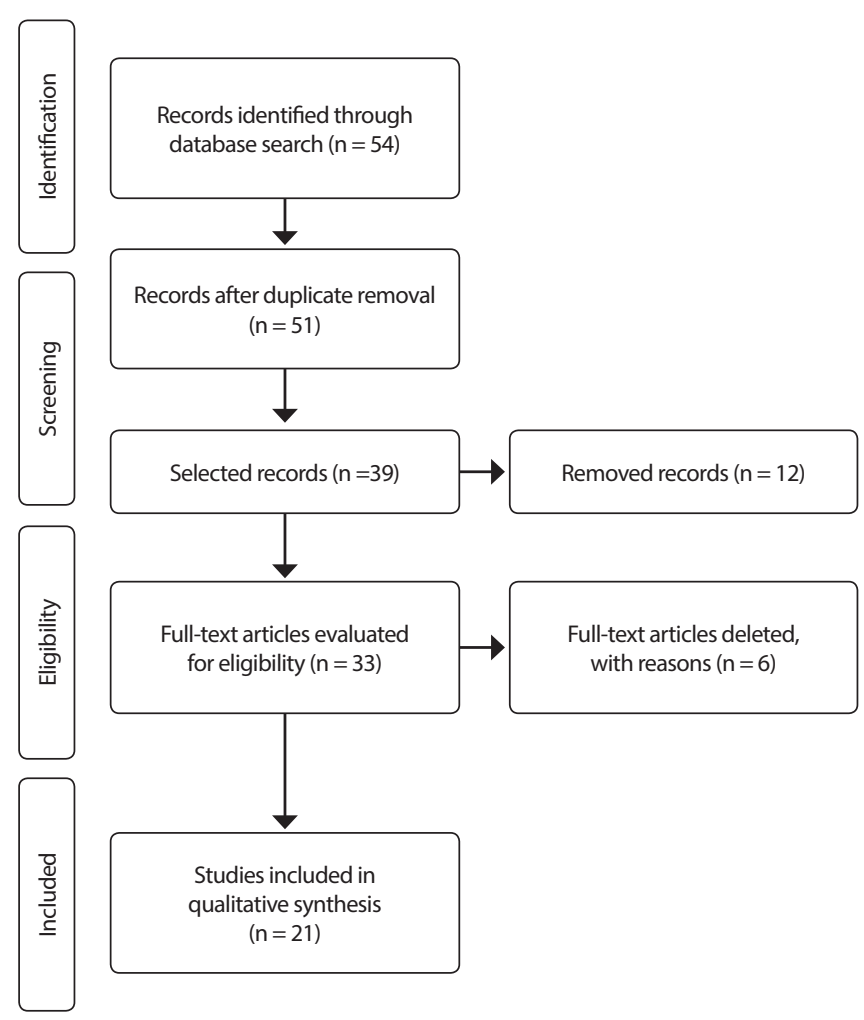

Figure 1 - Flowchart of the operationalization of the PRISMA review, Ribeirão Preto, São Paulo State, Brazil, 2017

To evaluate the quality of the selected studies, the Critical Appraisal Skills Program (CASP) was used, which was designed to measure the accuracy of qualitative studies. This tool consists of 10 questions regarding the description of the study objective, the type of qualitative methodology used, the study design, the recruitment strategies of the participants, data collection, the relationship between the researcher and the participant, regarding the considerations ethics, accuracy of the data analysis and how they were presented, besides the contributions of the studies ${ }^{(15)}$.

We highlight that the Microsoft Office Excel 2013 program was used to organize the studies in spreadsheets, and then the results were summarized in a synoptic table (Table 1). Subsequently, the results were analyzed based on the inductive thematic analysis ${ }^{(16)}$, following the following proposed steps: familiarization with the data, generation of codes, search for themes, continuous revision of the themes, definition of the themes and production of an explanatory interpretation.

We also point out that ethical issues and authorship rules were respected, and all articles consulted are cited and referenced throughout this study, as provided for in Law 9,610 of February 19,1998, which deals with copyright ${ }^{(17)}$.

Table 1 - Quality evaluation of the studies included in the Critical Appraisal Skills Program (CASP) according to the answers of the articles for each question, Ribeirão Preto, São Paulo State, Brazil, 2017

\begin{tabular}{|c|c|c|c|}
\hline Question & $\begin{array}{l}\text { Yes } \\
\left(n^{\circ}\right)\end{array}$ & $\begin{array}{l}\text { Patially } \\
\text { reported } \\
\left(n^{\circ}\right)\end{array}$ & $\begin{array}{l}\text { No } \\
\left(n^{\circ}\right)\end{array}$ \\
\hline 1. Were the research objectives clearly stated? & 19 & 1 & 1 \\
\hline 2. Is the qualitative methodology adequate? & 17 & 3 & 1 \\
\hline $\begin{array}{l}\text { 3. Was the design of the research adequate for the } \\
\text { achievement of the proposed objectives? }\end{array}$ & 16 & 5 & - \\
\hline $\begin{array}{l}\text { 4. Was the recruitment strategy adequate to the } \\
\text { research objectives? }\end{array}$ & 17 & 2 & 2 \\
\hline $\begin{array}{l}\text { 5. Were the data collected to address the research } \\
\text { question? }\end{array}$ & 18 & 3 & - \\
\hline $\begin{array}{l}\text { 6. Was the relationship between the researcher } \\
\text { and the participants properly considered? }\end{array}$ & 11 & 4 & 6 \\
\hline 7. Have ethical questions been considered? & 8 & 8 & 5 \\
\hline 8. Was the analysis of the data sufficiently accurate? & 20 & 1 & - \\
\hline 9. Were the results clearly reported? & 20 & 1 & - \\
\hline 10. Does the research bring contributions? & 11 & 9 & 1 \\
\hline
\end{tabular}

\section{RESULTS}

After the search, according to established criteria, the sample was represented by 21 articles of methodological approach, qualitative and with various theoretical references such as: symbolic interactionism, anthropology, phenomenology, social representation, among others, where one of the works was described in the Portuguese language and 20 in English. In order to collect data, the authors used the method of semi-structured interview, focal group, participant observation, life history and questionnaires, in the organization of the data, the researchers applied descriptive statistical analysis, collective subject discourse, thematic analysis, discourse analysis and content analysis.

As highlighted in Figure 2, we show that the studies related to masculinities among PC patients, the majority of authors are authors of $42.85 \%$, followed by nurses with $23.80 \%$, psychologists and nutritionists with $14.28 \%$ each and $4.76 \%$ by sociologists. The area of knowledge in which these professionals disseminated 
their research results focused mainly on responding to Oncology problems $76.19 \%$, and subareas with values of $42.85 \%$ for Medicine, $19.04 \%$ for Nursing and also Psychology, followed by $14.28 \%$ for Nutrition and $4.76 \%$ for Public Health. As for the articles published per year, it was observed the growth of publications with a maximum number of $38.09 \%$ of these in the year 2013 .

With regard to the origin place of the publications, they were mainly concentrated in North American countries (33.33\%) and European countries (33.3\%), and fewer in the countries of Oceania (23.80\%) and the Americas (9.52\%) in the study period.

As the selected references are based on an approach that relates men, culture and social, we adopt the multiple masculinities perspective to evaluate the adequacy of results and discussions of the studies to the hegemonic, subordinate, accomplice or marginalized masculinity standards $s^{(9)}$.
Chart 1 presents the knowledge produced in the health literature about the relationship established between the masculinities and the PC survivors, highlighting the implications of this relationship for the maintenance of human health, as well as the masculinity perspective and the objectives addressed in the studies analyzed.

Through the inductive thematic analysis, we organize in an explanatory and comprehensive way the following themes: Topic 1 - About the scientific production of masculinities in the context of survivors; Topic 2 - Prostate cancer, masculinities and their inharmonious relationships and Theme 3 - Implications of masculinities for human health and Nursing care, which will be discussed below.

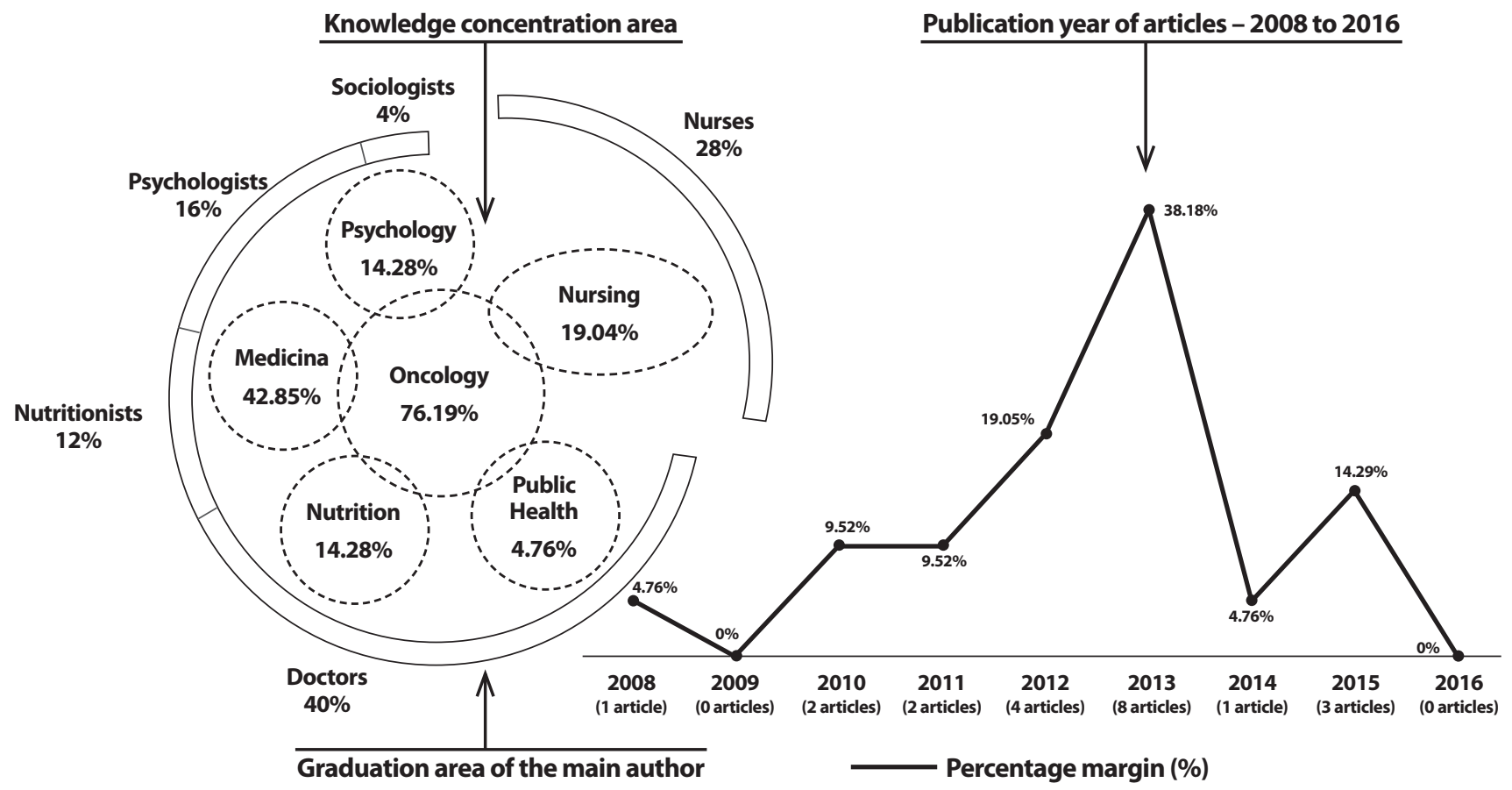

Figure 2 - Distribution of articles analyzed by graduation area of the main author/knowledge concentration area and year of publication - 2008 to 2016 , Ribeirão Preto, São Paulo State, Brazil, 2017

Chart 1 - Description of articles analyzed, 2008 to 2016, Ribeirão Preto, São Paulo State, 2017

\begin{tabular}{|l|l|l|}
\hline \multicolumn{1}{|c|}{ Title } & \multicolumn{1}{|c|}{ Objective } & \multicolumn{1}{c|}{ Relation between PC and Masculinity } \\
\hline $\begin{array}{l}\text { Impaired sexual function and } \\
\text { prostate cancer: a mixed method } \\
\text { investigation into the experiences of } \\
\text { men and their partners }\end{array}$ & $\begin{array}{l}\text { (1) } \\
\text { To explore issues related to sexual relations, } \\
\text { by men and their wives or partners, after the } \\
\text { diagnosis and PC doctor treatment. }\end{array}$ & $\begin{array}{l}\text { Men believed that PC and change in their sexual function } \\
\text { did not impact their masculinity, stimulating health care } \\
\text { neglect. However, their partners felt that their masculinity } \\
\text { was modified after the PC. }\end{array}$ \\
\hline $\begin{array}{l}\text { As arranhaduras da masculinidade: } \\
\text { uma discussão sobre o toque retal } \\
\text { como medida de prevenção do câncer } \\
\text { prostático(18) }\end{array}$ & $\begin{array}{l}\text { To analyze the meanings attributed to } \\
\text { the rectal touch, seeking to reflect on the } \\
\text { underlying issues of masculine speech from } \\
\text { aspects of the hegemonic model of masculinity. }\end{array}$ & $\begin{array}{l}\text { The rectal examination does not only touch the prostate, } \\
\text { it touches on several symbolic aspects of what it is to be } \\
\text { masculine, implying health care. }\end{array}$ \\
\hline $\begin{array}{l}\text { Dealing with a troublesome body: A } \\
\text { qualitative interview study of men's } \\
\text { experiences living with prostate cancer } \\
\text { treated with endocrine therapy }\end{array}$ & $\begin{array}{l}\text { To present the experiences of men with PC } \\
\text { in the face of bodily changes and how these } \\
\text { changes influence their daily lives. }\end{array}$ & $\begin{array}{l}\text { The body is a way of demonstrating masculinity. A } \\
\text { weakening of the body is interpreted by the sick as a threat } \\
\text { to masculine values. Influencing significantly on how men } \\
\text { perceive and take care of their body. }\end{array}$ \\
\hline
\end{tabular}


Chart 1

Embracing life after prostate cancer. A male perspective on treatment and rehabilitation ${ }^{(20)}$
To explore the experiences of radiotherapy treatment of participants in PC rehabilitation program and address the spouse's involvement in the rehabilitation process.

Bodily changes and lack of sexual practices had a major impact on how participants felt as men versus radiotherapy in treating PC. This treatment threatens the relationship between the spouses to put in judgment the masculinity of the sick person, which makes difficult in the rehabilitation.

The language around the $P C$ is not so clear and enlightening. This leads to a process of disinformation for the sick person, making decisions difficult, which is followed by certain treatments that expose them to effects on their self-image and physical health, thus threatening their masculinity. decision-making. patients $^{(21)}$

'You know I've joined your club... I'm the hot flush boy': a qualitative exploration of hot flushes and night sweats in men undergoing androgen deprivation therapy for prostate cancer ${ }^{(22)}$

Perceptions of physically active men with prostate cancer on the role of physical activity in maintaining their quality of life: possible influence of androgen deprivation therapy ${ }^{(23)}$

To analyze symptoms such as hot flashes and night sweats developed in men with PC after androgen deprivation therapy.

Androgen deprivation therapy promotes reactions similar to female menopause. These affect the beliefs of male hegemonic behaviors related to inability to meet their expectations with their traditional gender roles in terms of physical activity, work and sexual activity.

To analyze the perceptions of older men with PC regarding their quality of life and physical activity after diagnosis, the potential benefits and risks associated with being physically active.

Androgen therapy reduces the level of quality of life, leading to decline or cessation of sexual activity and greater concern with the return of their physical activities. These effects affect the way men perceive their masculinity.

The PC led men to experience deprivation of sexual activity as well as the devaluation of male self-image, since they developed unsatisfactory male behaviors such as: difficulty in achieving erection, non-ejaculation, and decreased sexual desire.

to erectile dysfunction and the decrease of masculinity among men treated by PC.

affection, and sexual bother in mer with localized prostate cancer $^{(24)}$

To observe the role of Nutrition in PC prevention and recovery due to observations that typical Western dietary pattern, foods rich in meat and fat, low fruit and vegetable consumption associated with high incidence and mortality.

Prostate cancer, masculinity and food. Rationales for perceived diet change $^{(25)}$

To explore the dietary practices of Canadian couples guided by a framework of gender relations to expose how performances of masculinity and femininity interact to shape

the diets of men with PC. and diet: Re-inscribing hetero normative food practices ${ }^{(26)}$

Men, Food, and Prostate Cancer: Gender Influences on Men's Diets ${ }^{(27)}$

To develop nutritional interventions related to $\mathrm{PC}$ in men, in order to involve them in a healthy diet.

Masculinities and patient perspectives of communication about active surveillance for prostate cancer ${ }^{(28)}$

To describe the connections between masculinities and patient's perspectives on communication with male doctors.

Masculinity influences the choice of foods for PC patients. Understanding of male ideals helps to understand how men follow dietary change.

Men became more interested and involved in their diets after a PC diagnosis, a practice that can be interpreted as a project unrelated to a hegemonic role, inducing other masculinities in the face of the PC.

Some men with PC make changes in their daily lives, food is one of them. They change their diets with unhealthy, typically male, foods, and impede nutritionist interventions. This factor is an impediment to the promotion of health actions to man.

The men's ideals defended during the consultations influence what can be understood as useful and useless communication between male patients and physicians, concerning the PC impacts. Doctors' communication to patients was viewed as a threat to male ideals by promoting hierarchies that broke the trust alliance between them.

Having a PC is like having the elixir of life stolen because your sexuality ends and your masculinity is threatened. The men were concerned about their intimacy and the maintenance of their masculine identity, having difficulty relating intimately to their partner, to approach the subject with other people.

PC causes psychological sequels, including vulnerability and uncertainties about the future related to work. It hinders the maintenance of the work routine due to the side effects of the treatments. Work is highlighted as a value of masculinity, and the side effects of treatments have implications for maintaining this identity. survivors and describe the links between masculinity and work after PC treatment.

ing treatment for prostate cancer ${ }^{(30)}$

To identify the social representations of men about the $P C$ and its masculinities in relation to the disease, and to analyze its implications for health.
The capacity for reproduction and pleasure are indispensable for the construction of traditional masculine identities. The PC leads to consequences such as impotence, which causes men to seek health care. This quest goes against the ideals of masculine virility. 


\begin{tabular}{|c|c|c|}
\hline $\begin{array}{l}\text { Re-constructing masculinity } \\
\text { following radical prostatectomy for } \\
\text { prostate cancer }^{(32)}\end{array}$ & $\begin{array}{l}\text { To investigate how men build and rebuild } \\
\text { their masculinities after radical prostatectomy } \\
\text { for the PC. }\end{array}$ & $\begin{array}{l}\text { Erectile dysfunction among prostatectomized men fuels } \\
\text { the belief that cancer is inconsistent with the role of gender } \\
\text { or sense of masculinity as it has a major impact on the } \\
\text { masculine identity of men. Those who cannot achieve } \\
\text { erection and pleasure for the judged as having a trivialized } \\
\text { masculinity. }\end{array}$ \\
\hline $\begin{array}{l}\text { The impact of prostate cancer on } \\
\text { partners: a qualitative exploration }{ }^{(33)}\end{array}$ & $\begin{array}{l}\text { To explore experiences of spouses or intimate } \\
\text { partners of men diagnosed and/or treated to } \\
\text { understand the personal impact of the PC on } \\
\text { the partner. }\end{array}$ & $\begin{array}{l}\text { Coping with the PC and the decrease of the masculinity } \\
\text { coming with the treatments demand a dedication not } \\
\text { only of the sick but also of their spouses. The spouses who } \\
\text { were active in supporting the sick, reported feeling more } \\
\text { adapted and secure to face changes in the masculinity of } \\
\text { the partner. }\end{array}$ \\
\hline $\begin{array}{l}\text { Talking about sexuality: desire, } \\
\text { virility, and intimacy in the context } \\
\text { of prostate cancer associations }{ }^{(34)}\end{array}$ & $\begin{array}{l}\text { To explore how some Swedish men } \\
\text { experience and communicate their sexuality. }\end{array}$ & $\begin{array}{l}\text { The PC and its impacts on the masculinity of the sick have } \\
\text { been identified as a threat to the male identity due to } \\
\text { loss of libido and vulnerability. These issues were difficult } \\
\text { to share in gender-based social judgment. Masculinities } \\
\text { defended before the disease are confronted with the } \\
\text { sexuality change. }\end{array}$ \\
\hline $\begin{array}{l}\text { Sexuality and exercise in men } \\
\text { undergoing androgen deprivation } \\
\text { therapy for prostate cancer }{ }^{(35)}\end{array}$ & $\begin{array}{l}\text { To explore the impact of androgen deprivation } \\
\text { therapy on the sexuality of men with PC and } \\
\text { the effects of exercise on this experience. }\end{array}$ & $\begin{array}{l}\text { Treatment against PC led participants to experience } \\
\text { decreased sexual desire, decreased erection, erectile } \\
\text { dysfunction, and lack of orgasm or libido. These } \\
\text { experiences interfered in the representation of } \\
\text { masculinities in society. The practice of exercise helped to } \\
\text { manage this experience positively. }\end{array}$ \\
\hline $\begin{array}{l}\text { Defining young in the context of } \\
\text { prostate cancer }{ }^{(36)}\end{array}$ & $\begin{array}{l}\text { Interpretive phenomenological analysis to } \\
\text { define what it means to be young and to have } \\
\text { prostate cancer. }\end{array}$ & $\begin{array}{l}\text { Male constructs and life-course perspectives are important } \\
\text { concepts that help expand our understanding of "being } \\
\text { young with prostate cancer" beyond chronological age. }\end{array}$ \\
\hline $\begin{array}{l}\text { The impact of prostate cancer on } \\
\text { men's everyday life }^{(37)}\end{array}$ & $\begin{array}{l}\text { It highlights how men deal with the disease } \\
\text { and treatment and the strategies they employ } \\
\text { to manage their diagnosis next to daily life. }\end{array}$ & $\begin{array}{l}\text { The impact of the research procedures emerged as } \\
\text { particularly significant in the way men adjusted and } \\
\text { handled their diagnosis. }\end{array}$ \\
\hline
\end{tabular}

\section{DISCUSSION}

\section{Theme 1 - About the scientific production of masculinities in the context of survivors}

Based on the results, we analyzed that Medicine is the main area of knowledge with a focus on understanding the masculinityrelated issues among PC survivors and also to disseminate the results of their research in strengthening the Oncology knowledge and of their own science base.

Research related to PC and masculinity in the last eight years has focused its objectives on quite different topics, such as the following: PC screening, description of male experiences related to signs and symptoms of andropause, involvement of spouses in the rehabilitation process and the coping with the impact of the hegemonic masculinity change in the life of the caregivers, besides the exploration and explanation of the implications for the health of the man in the face of prostatectomy, androgen deprivation therapy and radiotherapy, which provoked corporal changes and cultural habits presented by the presence of sexual dysfunctions, readaptation of physical activity practices, choice of certain diets and meaning of work.

Also in this corpus there was the understanding of the communication between doctors and patients and their influence on the adherence of treatments for the sick. However, we emphasize that the most focused theme in the studies was the search for the understanding of aspects related to sexuality and the maintenance of the quality of life of PC survivors.
Regarding the masculinity view defended in the studies analyzed, the hegemonic perspective was unanimous, leaving the multiple masculinities on the margins of these discourses. Anchored in the anthropological point of view of masculinities ${ }^{(9)}$, we understand that in the phenomenon of involvement among PC survivors and in the construction of masculinities, coexisting webs of meanings that point to the existence of other conceptions. These are in constant dispute with each other for the adequacy of standards considered as hegemonic, whether local or global, present within a culture ${ }^{(26,38)}$.

Therefore, research on marginalized, complicit, subordinate masculinities among the surviving men of PC was not highlighted among the studies analyzed, but certainly could provide theoretical support for the analysis of future research.

\section{Theme 2 - Prostate cancer, masculinities and their inhar- monious relationships}

When analyzing the studies, we show that $23.8 \%$ of them emphasize that the illness, the non-dominance of the body and the vulnerability are assumed as threatening the maintenance of a hegemonic masculinity among the PC survivors.

The anthropology of masculinities ${ }^{(9,39-40)}$ argues that the body is an object full of symbols and meanings, through which man communicates in his social environment. The masculine body is defended hegemonically as strong, potent and has dominion over other bodies ${ }^{(9)}$. Thus, the man who falls ill with PC distances himself from the defense of male hegemony and is vulnerable to the experience of other masculinities. 
The communication process about the disease, the treatments and the masculine values surrounding the PC were also highlighted in $14.3 \%$ of the publications. Studies have pointed out that this relationship is deficient and, in some cases, generate hierarchies and disinformation that threaten male ideals such as strength, power and domination.

Researchers ${ }^{(6,10,40)}$ emphasize that hegemonic masculinity is sustained by power relations with other masculinities subordinate to it. For man, this implies in the defense of a hierarchical position of domination over other men, women and behaviors that deny the embodiment of illness, debilitation and vulnerability ${ }^{(6,10)}$. Thus, to maintain this masculinity socially, men end up adopting actions such as the neglect of health care and the non-relation of information that makes it possible to contribute to the provision of care to this population.

As observed in $9.5 \%$ of the studies analyzed, the screening tests for PC threaten various social symbols and behaviors of men that fit into a local hegemonic masculinity, such as: the anal region being a sensitive region and untouchable by other men, the penetration in the anal region is associated with a homosexual act and the fact that the man defends his intimacy of the genitals is inviolable.

These hegemonic principles reinforce behavior that distances men from the search for health care, they do not fit into these symbolic assertions and are considered as deserters of these values $^{(7)}$. Even though they do not conform to all the symbolic precepts because they experience illness by PC, many men are accomplices in nurturing the status of mastery created for masculinity. Socially, the practice of defending male hegemony is interpreted as a common behavior that is highlighted in the power relations established among men ${ }^{(28,38)}$.

Another aspect highlighted in the studies analyzed was the side effects of pc treatments. $28.57 \%$ of the studies emphasized that they modify the self-image of the man, his physical vigor and his masculine roles before the family, companions and work.

Self-image change and masculinities is an imperative little explored in research on the subject, but some studies ${ }^{(7,41)}$ point out that this relation modifies the quality of life of the survivors and the way they mean their masculinities in their social environment. His body expression is ill or modified due to the side effects of the treatments, it is associated with a process of femininity, which threatens the maintenance of its hegemonic masculinity and, consequently, of the space for the articulation of new masculinities.

After analyzing the results of the studies, we identified that PC interferes in the development of the attributes related to the sexuality of the man like desire, libido and erection, provoking sexual dysfunctions that significantly diminish their quality of life. This impact on sexuality, as evidenced in $47.61 \%$ of the studies, directly influences how man, intimate partner, and society relate masculinity to the gender identity of the survivor.

In this perspective, Psychology studies offer a literary collection that helps the researchers to answer the reason of the occurrence of this phenomenon among the men. Psychology understands sexuality as an intrinsic imperative to masculinity. Therefore, sexual dysfunctions threaten the precepts of domination and place man in a dominated position, thus breaking with hegemonic ideals ${ }^{(38,42)}$.
We emphasize the need for articulations of studies that focus on other perspectives, not only the psychosocial ones, because we understand that there is still a shortage of studies that discuss this relationship under a cultural, hermeneutical, historical, dialectical and social approach, among others, as a research field replete with symbols to be investigated and discovered.

We observed that the cultural factors involved in feeding the survivors were the focus of $14.28 \%$ of the analyzed publications. Studies report that men are reproducing food ideals specific to certain hegemonic patterns of masculinities, such as poor in fiber and vitamins, and rich in carbohydrates and proteins. PC disease induces men to change their reproductive patterns of the norms defended in their local masculinities.

Scholars ${ }^{(29)}$ point out that although changes in habits converge in the adoption of healthy eating practices, many PC survivors still share cultural norms and standards that hinder adherence to healthy diets. This behavioral characteristic is linked to the various meanings that food and the habit of eating are configured for male culture. For this genre, the adoption of less protein diets is associated with the typical female diet, which, within a hegemonic culture, are subservient to the patterns of domination expected socially by men ${ }^{(41-42)}$.

\section{Theme 3 - Implications of masculinities for human health and Nursing care}

Based on the results presented, we understand that there is a disharmonious relation between PC and the maintenance of hegemonic masculinities by the survivors. The possible contexts of coexistence between them indicated several implications for human health, as demonstrated in $39 \%$ of the studies analyzed. The authors of the publications affirm that the maintenance of this association stimulates the way these subjects perceive and take care of their body, which in many cases, so that their masculinity remains untouched, end up neglecting health care.

It has also been shown in $24 \%$ of studies that this connection makes it difficult for spouse relationships, family support and decision-making regarding the search for coping strategies. $28.5 \%$ of the studies emphasize that this relationship also makes it difficult to comply with healthy diets and to reduce the quality of life due to the decline in physical and psychological health. In $19 \%$ of articles, it was discussed that this relationship promotes hierarchies in the communication between doctors, patients and society, making it difficult to maintain work and acceptance of changes in sexuality after the treatments.

In this context, according to the health implications found, authors $^{(4-7)}$ point out that hegemonic models of masculinities make it difficult to adopt healthy habits, since men, when influenced by hegemonic ideals, may devalue their self-care by crediting this action to female behavior, which endangers the maintenance of his health.

As nurses, we understand that the implications of this relationship highlight several interventions for Nursing professionals. Among them, we pointed out the need to develop greater PC prevention and control actions, as well as the implementation of strategies that promote continuing education specific to the particularities of masculinities presented by the survivors. Therefore, 
knowing the masculinities of PC survivors is a first step towards the articulation of effective measures in the search for the quality of care integrated to this gender in the philosophy of Nursing.

\section{Study limitations}

While this initiative of systematically reviewing the PC's relationship to masculinities seems to be the first of its kind, it is not a flawless attempt, and there are certainly limitations that need to be highlighted. In the first place we point to the time interval investigated; we believe that a larger temporal cut would present other evidence to be analyzed in this perspective. Secondly, we emphasize that some studies did not present descriptors and did not present sufficient elements that could be included in this study.

Thirdly, we would point out that the focus of our study was limited only to PC survivors, certainly if we observed results of studies in a more general way, that approached men before or during PC treatment, other masculinities could be addressed. Finally, since the masculinity of ill men is related to culture, the cultural variation of the studies indicates another possible limitation, as well as the differences between generations, social classes and age groups.

\section{Contributions to the sector of Nursing}

The results of this metasynthesis help to guide the provision of qualified care to men who are ill with $P C$, in order to strengthen them and assist them in care relationships. However, we pointed out that there are several knowledge gaps that subsidized the theme among the analyzed references, such as the transformations of masculinities in the face of PC, the socialization of masculinities of the sick, the re-signification of masculinities at work, in the family and in social groups in the which men are inserted, among others. This knowledge, as well as those highlighted in this research, also imply important contributions to the clinical and educational practice of men who are ill and should be investigated. We therefore recommend that future research be developed addressing these and other relevant health topics of this group.

\section{FINAL CONSIDERATIONS}

The presented metasynthesis allowed to synthesize the knowledge published in the health literature on masculinities in the context of PC survivors and to interpret the implications of this relation for the maintenance of men's health. It was concluded that screening tests, experiences related to signs and symptoms of andropause, involvement of spouses in the rehabilitation process, alteration of hegemonic masculinity defended, changes caused by sexual dysfunctions, rehabilitation of activity practices physics and nutrition, besides the aspects related to the maintenance of the quality of life, were the main characteristics evidenced. The defense of hegemonic masculinity in face of these experiences brought implications for the health care to the men, making communication difficult on the disease, adherence to the treatments, the relationship between the spouses and the family support, mainly influencing the neglect of health care.

\section{FUNDING}

This study was funded by the National Council of Scientific and Technological Development (CNPq - Conselho Nacional de Desenvolvimento Científico e Tecnológico), Processes 161735/20126 and 305368/2014-1.

\section{REFERENCES}

1. Siegel R, Ma J, Zou Z, Jemal A. Cancer Statistics, 2015. CA Cancer J Clin. 2015;65(1):5-29. doi: 10.3322/caac.21254

2. Ministério da Saúde (BR), Instituto Nacional de Câncer José Alencar Gomes da Silva (INCA). Estimativa 2016/2017: Incidência de câncer no Brasil [Internet]. Rio de Janeiro: INCA; 2016 [cited 2016 Jan 22]. Available from: http://www.inca.gov.br/estimativa/2016/estimativa2016-v11.pdf

3. Mottet N, Bellmunt J, Briers E, Van den Bergh RCN, Bolla M, Van Casteren NJ, et al. Guidelines on prostate cancer. European Association of Urology. [place unknown]: EAU, ESTRO, SIOG; 2015 [cited 2006 Jan 20]. 146 p. Available from: http://uroweb.org/individual-guidelines/ oncology-guidelines/

4. Appleton L, Wyatt D, Perkins E, Parker C, Crane L, Jones A, et al. The impact of prostate cancer on men's everyday life. Eur J Cancer Care (Engl). 2015;24(1):71-84. doi: 10.1111/ecc.12233

5. Krumwiede KA, Krumwiede N. The lived experience of men diagnosed with prostate cancer. Oncol Nurs Forum. 2012;39(5):E443-E450. doi: 10.1188/12.ONF.E443-E450

6. Connell RW, Messerschmidt JW, Hegemonic masculinity. Rethinking the concept. Gend Soc [Internet]. 2005 [cited 2018 Nov 03];19(6):829859. Available from: https://doi.org/10.1177/0891243205278639

7. Stapleton S, Pattison N. The lived experience of men with advanced cancer in relation to their perceptions of masculinity: a qualitative phenomenological study. J Clin Nurs. 2015;24(7):1069-1078. doi:10.1111/jocn.12713

8. Connell RW. Gender: in world perspective. 2nd ed. Cambridge (UK): Polity Press; 2012. 170 p.

9. Connell RW. Masculinities. 2nd ed. Berkeley (LA): University of California Pressed; 2005. 311 p.

10. Evans J, Frank B, Oliffe JL, Gregory D. Health, illness, men and masculinities (HIMM): a theoretical framework for understanding men and their health. J Mens Health [Internet]. 2011 [cited 2018 Nov 03];8(1):7-15. Available from: https://doi.org/10.1016/j.jomh.2010.09.227 
11. Barnett-Page E, Thomas J. Methods for the synthesis of qualitative research: a critical review. BMC Med Res Methodol [Internet]. 2009 [cited 2018 Nov 03];9:59. Available from: https://doi.org/10.1186/1471-2288-9-59

12. De-la-Torre-Ugarte-Guanilo MC, Takahashi RF, Bertolozzi MR. Systematic review: general notions. Rev Esc Enferm USP [Internet]. 2011 [cited 2018 Nov 03];45(5):1255-1261. Available from: http://dx.doi.org/10.1590/S0080-62342011000500033

13. Moher D, Liberati A, Tetzlaff J, Altman DG; PRISMA Group. Preferred reporting items for systematic reviews and meta-analyses: the PRISMA statement. PLoS Med. 2009;6(7):e1000097. doi:10.1371/journal.pmed.1000097

14. Tong A, Flemming K, Mclnnes E, Oliver S, Craig j. Enhancing transparency in reporting the synthesis of qualitative research: ENTREQ. BMC Med Res Methodol [Internet]. 2012 [cited 2018 Nov 03];12:181. Available from: https://doi.org/10.1186/1471-2288-12-181

15. Singh J. Critical appraisal skills programme. J Pharmacol Pharmacother [Internet]. 2013 [cited 2018 Nov 03];4:76-7. Available from: doi:10.4103/0976-500X.107697

16. Braun V, Clarkc V. Using thematic analysis in psychology. Qual Res Psychol [Internet]. 2006 [cited 2018 Nov 03];3(2):77-101. Available from: http://dx.doi.org/10.1191/1478088706qp063oa

17. Presidência da República (BR), Casa Civil, Subchefia para Assuntos Jurídicos. Lei n. 9.610, de fevereiro de 1998. Altera, atualiza e consolida a legislação sobre direitos autorais e dá outras providências [Internet]. Diário Oficial da União: República Federativa do Brasil. 1998 [cited 2018 Nov 3]. Fev 20, Seção 1: [about 15 screens]. Available from: http://www.planalto.gov.br/ccivil_03/Leis/L9610.htm

18. Gomes R, Nascimento EF, Rebello LEFS, Araújo FC. [The touched masculinity: a discussion about the digital rectal exam for prostate cancer Prevention]. Ciênc Saude Colet [Internet]. 2008 [cited 2018 Nov 03];13(6):1975-1984. Available from: http://dx.doi.org/10.1590/ S141381232008000600033 Portuguese.

19. Ervik B, Asplund K. Dealing with a troublesome body: a qualitative interview study of men's experiences living with prostate câncer treated with endocrine therapy. Eur J Oncol Nurs [Internet]. 2012 [cited 2018 Nov 03];16(2):103-108. Available from: doi:10.1016/j.ejon.2011.04.005

20. Dieperink KB, Wagner L, Hansen S, Hansen O. Embracing life after prostate cancer. A male perspective on treatment and rehabilitation. Eur J Cancer Care (Engl) [Internet]. 2013 [cited 2018 Nov 03];22(4):549-558. Available from: https://doi.org/10.1111/ecc.12061

21. Rot, I, Ogah I, Wassersug RJ. The language of prostate cancer treatments and implications for informed decision making by patients. Eur J Cancer Care (Engl) [Internet]. 2012 [cited 2018 Nov 03];21(6):766-775. Available from: doi:10.1111/j.1365-2354.2012.01359.x

22. Eziefula CU, Grunfeld EA, Hunter MS. 'You know I've joined your club... I'm the hot flush boy': A qualitative exploration of hot flushes and night sweats in men undergoing androgen deprivation therapy for prostate cancer. Psychooncology. 2013;22(12):2823-2830. doi: 10.1002/ pon.3355

23. Keogh JWL, Patel A, MacLeod RD, Masters J. Perceptions of physically active men with prostate cancer on the role of physical activity in maintaining their quality of life: possible influence of androgen deprivation therapy. Psychooncology. 2013;22(12):2869-75. doi: 10.1002/ pon.3363

24. Zaider T, Manne S, Nelson C, Mulhall J, Kissane D. Loss of masculine identity, marital affection, and sexual bother in men with localized prostate cancer. J Sex Med 2010;9(10):2724-2732. doi: 10.1111/j.1743-6109.2012.02897.x

25. Mróz LW, Chapman GE, Oliffe JL, Bottorff JL. Prostate cancer, masculinity and food: rationales for perceived diet change. Appetite. 2010; 55(3):398-406. doi: 10.1016/j.appet.2010.07.009

26. Mróz LW, Chapman GE, Oliffe JL, Bottorff JL. Gender relations, prostate cancer and diet: re-inscribing hetero-normative food practices. Soc Sci Med. 2011;72(9):1499-1506. doi: 10.1016/j.socscimed.2011.03.012

27. Mróz LW, Chapman GE, Oliffe JL, Bottorff JL. Men, food, and prostate cancer: gender influences on men's diets. Am J Mens Health. 2011;55(2):177-87. doi: 10.1177/1557988310379152

28. Oliffe JL, Mróz LW, Davison BJ. Masculinities and patient perspectives of communication about active surveillance for prostate cancer. Health Psychol. 2013;32(1):83-90. doi:n10.1037/a0029934

29. Klaeson K, Sandell K, Bertero CM. Sexuality in the context of prostate cancer narratives. Qual Health Res. 2012;22(9):1184-1194. doi: $10.1177 / 1049732312449208$

30. Grunfeld, EA, Coates LD. "The only way I know how to live Is to work": A qualitative study of work following treatment for prostate cancer. Health Psychol. 2013;32(1):75-82. doi: 10.1037/a0030387

31. Araujo JS, Conceição VM, Silva SED, Santana ME, Vasconcelos EV, Sousa RF. The social representations of men about prostate cancer. Rev Pesqui Cuid Fundam [Internet]. 2013 [cited 2018 Nov 03];5(2):3893-3884. Available from: doi: 10.9789/2175-5361.2013v5n2p3884

32. Gannon K, Blanco MG, Patel A, Abel P. Re-constructing masculinity following radical prostatectomy for prostate cancer. Aging Male. 2010;13(4):258-64. doi: 10.3109/13685538.2010.487554

33. Wootten AC, Abbott JM, Osborne D, Austin DW, Klein B, Costello AJ, et al. The impact of prostate cancer on partners: a qualitative exploration. Psychooncology. 2014;23(11):1252-8. doi: 10.1002/pon.3552

34. Klaeson K, Sandell K, Berterö CM. Talking about sexuality: desire, virility, and Intimacy in the context of prostate cancer associations. Am J Mens Health. 2013;7(1):42-53. doi: 10.1177/1557988312458143

35. Hamilton K, Chambers SK, Legg M, Oliffe JL, Cormie L. Sexuality and exercise in men undergoing androgen deprivation therapy for prostate cancer. Support Care Cancer. 2014;23(1):133-42. doi: 10.1007/s00520-014-2327-8 
36. Chambers S K, Lowe A, Hyde M K, Zajdlewicz L, Gardiner R A, Sandoe D, Dunn J. Defining young in the context of prostate cancer. Am J Mens Health. 2015;9(2):103-114. doi: 10.1177/1557988314529991

37. Appleton L, Wyatt D, Perkins E, Parker C, Crane J, Jones A, Moorhead L, Brown V, Wall C, Pagett M. The impact of prostate cancer on men's everyday life. Eur J Cancer Care (Engl). 2015;24(1):71-84. doi: 10.1111/ecc.12233.

38. Connell RW. Gender and embodiment in world society. Rev Luso Estud Cult [Internet]. 2015 [cited 2016 Jan 23];3(1):289-95. Available from: http://estudosculturais.com/revistalusofona/index.php/rlec/article/view/216/139

39. Harrington JM. Implications of treatment on body image and quality of life. Semin Oncol Nurs [Internet]. 2011 [cited 2018 Nov 03];27(4)290299. Available from: doi: 10.1016/j.soncn.2011.07.007

40. Modena CM, Martins AM, Gazzinelli AP, Schall SSL, Almeida VT. [Cancer and masculinities: meanings attributed to illness and to oncology treatment]. Temas Psciol [Internet]. 2014 [cited 2018 Nov 03];22(1):67-78. Available from: doi:10.9788/TP2014.1-06 Portuguese.

41. Avery KN, Donovan JL, Horwood J, Neal DE, Hamdy FC, Parker C, et al. The importance of dietary change for men diagnosed with and at risk of prostate cancer: a multi-centre interview study with men, their partners and health professionals. BMC Fam Pract. 2014;15:81. doi: 10.1186/1471-2296-15-81

42. Mróz LW, Robertson S. Gender relations and couple negotiations of British men's food practice changes after prostate cancer. Appetite. 2015;84:113-119. doi: 10.1016/j.appet.2014.09.026 